DOI 10.4467/2543733XSSB.21.018.13811

JAN RYCHLÍK

Uniwersytet Karola w Pradze

\title{
DYPLOMACJA CZECHOSLOWACKA WOBEC SYTUACJI W POLSCE W 1989 ROKU
}

\section{Czechoslovak Diplomacy in the Face of the Situation in Poland in 1989}

Summary

In 1989, the diplomacy of communist Czechoslovakia watched the political changes in communist Poland moving towards democratization with care and concern. However, due to the passive attitude of the Gorbachev ruler in Moscow, Prague did not intend to take any practical steps towards creating a political bloc proposed by Romania that could stop systemic changes in Poland. Despite the announcement of support for Polish communists, Prague chose to isolate Czechs and Slovaks from Poland and Poles and limit her own reforms to the economic sphere. It also did not open the border with Poland closed in 1981 for individual movement.

Key words: Czechoslovak diplomacy in 1989, Czechoslovak-Polish relations in 1989, the Czechoslovak-Polish border in 1989

Słowa kluczowe: dyplomacja czechosłowacka w 1989, stosunki czechosłowacko-polskie w 1989, granica czechosłowacko-polska w 1989

Polityka zagraniczna Czechosłowacji w latach tzw. normalizacji (1969-1989) kierowała się dwoma zasadami: pełnym trzymaniem się linii sowieckiej polityki zagranicznej we wszystkich obszarach oraz odrzucaniem wszelkich zmian w innych państwach socjalistycznych, które mogłyby potencjalnie zagrozić reżimowi komunistycznemu. Taką, pozbawioną w zasadzie własnych koncepcji linię reprezentował minister spraw zagranicznych Bohuslav Chn̆oupek, słowacki komunista i były korespondent moskiewskiego dziennika komunistycznego „Prawda” w Bratysławie, który kierował Ministerstwem Spraw Zagranicznych przez prawie siedemnaście lat - konkretnie od 9 grudnia 1971 do 12 października 1988 roku.

W przekonaniu władz komunistycznej Czechosłowacji, Polska Rzeczpospolita Ludowa od początku lat 80 . XX wieku stanowiła najsłabsze ogniwo w obozie państw socjali- 
stycznych. Nie licząc problemów ekonomicznych, aktywności antykomunistycznej opozycji, czy słabnących struktur i wpływów w społeczeństwie Polskiej Zjednoczonej Partii Robotniczej, także takie stałe, postrzegane negatywnie przez Prage polskie problemy, jak przeważający prywatny sektor w rolnictwie czy silna pozycja Kościoła katolickiego nieprzerwanie gościły na stronach przesyłanych z Warszawy czechosłowackich raportów dyplomatycznych ${ }^{1}$. Na niezbyt pozytywny bilans stosunków czechosłowacko-polskich składały się także nagromadzone, zwłaszcza między Polakami a Czechami, uwarunkowane historycznie, wzajemne uprzedzenia i stereotypy.

Po 1980 roku Praga na odcinku polskim myślała przede wszystkim o jednym - powstrzymać wpływy „solidarnościowej” rewolucji i ochronić rynek wewnętrzny, także poprzez zamknięcie granicy, co zrealizowano 7 grudnia 1981 roku, na kilka dni przed ogłoszeniem w PRL stanu wojennego, likwidując faktycznie na ponad dziesięć lat nie tylko indywidualny ruch turystyczny, ale i tzw. mały ruch graniczny. Przywódcy Czechosłowackiej Republiki Socjalistycznej (CSRS, Československá socialistická republika, ČSSR) podkreślali w spotkaniach z polskimi politykami, że ochrona własnego rynku konsumpcyjnego za wszelką cenę jest dla nich priorytetem. W drugiej połowie lat 80 . Praga nie podchodziła już jednak tak wiernopoddańczo jak wcześniej do lansowanej przez Moskwę w osobie Michaiła Gorbaczowa nowej polityki wewnętrznej i zagranicznej. Zainicjowana oficjalnie na XVII zjeździe Komunistycznej Partii Czechosłowacji (KPCz, Komunistická strana Československa, KSČ) w marcu 1986 roku czechosłowacka kopia pieriestrojki, czyli prestavba (przebudowa) na dłuższą metę okazała się bowiem jedynie niewiele znaczącą w życiu obywateli kosmetyką. W listopadzie 1987 roku z funkcji sekretarza generalnego KC KPCz ustąpił Gustáv Husák (zachowując urząd prezydenta państwa), którego zmienił Miloš Jakeš. W październiku 1988 roku premiera Lubomira Štrougala zastąpił Ladislav Adamec, a szefa dyplomacji Bohuslava Chňoupka - Jaromír Johanes (wcześniej wiceminister). Reżim trzymał się jednak w miarę dobrze.

Jak można było przypuszczać po doświadczeniach lat 1980-1981, o rozgrywających się w Polsce, od rozpoczęcia 6 lutego 1989 roku obrad Okrąłłego Stołu, przełomowych wydarzeniach prasa w Czechosłowacji początkowo informowała swoich obywateli co najwyżej w sposób zdawkowy, podkreślając przy tym swój negatywny stosunek do opozycyjnych partnerów strony rządowej. Zapoczątkowane rozmowy budziły w Pradze oczywiście zaniepokojenie, większe niż na przykład głośne wówczas wydarzenia związane z aktywizacją i wysiedleniami mniejszości tureckiej w komunistycznej Bułgarii. Obawy władz czechosłowackich zaczęły budzić także sąsiednie Węgry, choć sprawa polska miała jednak w pierwszej połowie 1989 roku większy ciężar gatunkowy. O zgodzie PZPR na rozmowy z opozycją Praga dowiedziała się od swoich dyplomatów w Moskwie już we wrześniu 1988 roku, gdy ambasador PRL Włodzimierz Natorf uzyskał w tej sprawie zgodę Kremla. Na początku lutego 1989 roku w Pradze gościł Wojciech Jaruzelski z misją „uspokajającą”. Towarzyszący mu minister Stanisław Ciosek zapewniał, że PZPR nie chodzi o rezygnację z socjalizmu, gdyż większość Polaków go popiera, ale z drugiej strony robotnicy stanowią tylko $37 \%$ jej członków².

\footnotetext{
${ }^{1}$ Szerzej zob. J. Rychlík, Politické změny ve Východni Evropě před 17. listopadem a jejich ohlas v Československu, „Česko-slovenská historická ročenka” 2009, s. 113-122.

${ }^{2}$ Ibidem, s. 123-125.
} 
W omawianym okresie, od października 1987 roku na stanowisku czechosłowackiego ambasadora w PRL pozostawał były minister oświaty Republiki Czeskiej, Josef Havlín, uważany za przeciwnika reform, a więc „twardogłowego”. Według ocen ambasady CSRS w Warszawie, Okragły Stół był kapitulacją władz przed opozycją. Gdy 25 lutego w Teatrze Powszechnym w Warszawie wystawiono premierowy spektakl Audiencji i Protestu, dwóch jednoaktówek więzionego podówczas w Czechosłowacji czeskiego dysydenta Václava Havla, Ambasada CSRS zareagowała negatywnie przede wszystkim dlatego, że wśród obecnych na przedstawieniu byli przedstawiciele władz państwowych, w tym premier PRL Mieczysław Rakowski, którego żona była aktorką tego teatru. Po zakończeniu spektaklu jeden z liderów opozycji, Adam Michnik, odczytał list w obronie Havla. Reakcja władz polskich musiała przekonać ambasadora, że w Polsce rzeczywiście nadchodzą zmiany nie po myśli Pragi. Według przekazu ministra kultury Aleksandra Krawczuka i odpowiedzialnych za sprawy kultury członków KC PZPR nie można już było bowiem w aktualnej sytuacji politycznej zabronić wystawienia tych sztuk, choć osoby te - według Havlína wyraziły politowanie, że przy okazji zorganizowano antyczechosłowacka kampanię, a opozycja wykorzystała premierę do ogłoszenia protestu przeciwko uwięzieniu Havla i wystapienie Michnika postawiło M. Rakowskiego w niezręcznej sytuacji. Chodziło o przemyślany i dobrze zorganizowany zamiar polskiej opozycji kulturalnej - podsumowywał Havlín. Czas, który temu przedstawieniu teatralnemu poświęciła polska telewizja, wybrzmiał jako kampania protestacyjna przeciwko uwięzieniu i skazaniu Havla, nawet gdy w sformułowaniach słownych redaktorom nie można nic wytknać. Obecność premiera dodała przedstawieniu niepotrzebnej popularności, z kolei publiczne wystapienie Michnika przestrzeń dla dwuznacznych niepotrzebnych interpretacji ${ }^{3}$.

Ważny dla dalszego śledzenia i oceny spraw polskich w optyce czechosłowackiej był przebieg posiedzenia Doradczego Komitetu Politycznego państw stron Układu Warszawskiego w dniach 7-8 lipca 1989 roku, na którym Czechosłowację reprezentował Miloš Jakeš. Choć pod wpływem Gorbaczowa zebrani zaaprobowali treść końcowego komunikatu mówiącego o nieistnieniu jednego, uniwersalnego modelu socjalizmu, podczas dyskusji o zachodzących w Europie zmianach politycznych wyraźnie jednak wyodrębniły się jakby dwa bloki: reformatorski - reprezentowany przez Polskę i Węgry oraz konserwatywny, czyli bułgarsko-rumuńsko-czechosłowacko-wschodnioniemiecki; z kolei ZSRR próbował zajmować jakby pozycję pośrednika. Przyczyniła się do tego nieoficjalna propozycja przywódcy rumuńskiego Nicolae Cauşescu, który potępiając „heretyckie” poglądy Węgrów o rozwiązywaniu aktualnych problemów poprzez demokratyzowanie realnego socjalizmu, zaproponował osobne spotkanie przywódców na ten temat. Zasugerował także nieoficjalnie Sofii, Pradze i Berlinowi utworzenie swoistej ,grupy konserwatywnej” jako przeciwwagi osi reformatorskiej Warszawa-Budapeszt. Według przekazów bułgarskich odrzucił to od razu Todor Żiwkow, Jakeš zajął postawę wyczekująca, a reakcji Ericha Honeckera nie znamy, choć można przypuszczać, że była podobna ${ }^{4}$. Sprawa ta nabrała aktualności, gdy 19 sierpnia nowym, desygnowanym przez prezydenta Wojciecha Jaru-

${ }^{3}$ Archiv Ministerstva zahraničních věcí Praha, Teritoriální odbory-tajné, Polsko (dalej AMZV, TOP), Nowa premiera dwóch jednoaktówek V. Havla w Teatrze Powszechnym w Warszawie, 27.02.1989, karton 2, čislo $01050 / 89$.

${ }^{4}$ J. Rychlík, Politické změny ve Východni Evropě..., s. 128-129. 
zelskiego, premierem polskiego rządu został przedstawiciel opozycyjnej „Solidarności”, Tadeusz Mazowiecki (powołany przez sejm 24 sierpnia), co zelektryzowało Pragę, Berlin i Bukareszt, ale ku ubolewaniu tych stolic już nie Moskwę.

Już zresztą w tym samym dniu dyplomacja CSRS w Polsce po raz kolejny musiała przełknąć gorzką pigułkę. Chodziło o zaproponowaną przez opozycyjny Obywatelski Klub Parlamentarny i przyjętą przez nowy polski sejm uchwałę potępiającą wkroczenie wojsk Układu Warszawskiego do Czechosłowacji w 1968 roku i udział w niej wojsk polskich, z okazji 21 rocznicy tego wydarzenia. Podważało to legitymizacją rządzącej w Pradze ekipy, która uformowała się dzięki stłumieniu Praskiej Wiosny, tym bardziej że za rezolucją głosował także klub poselski PZPR. Jak donosił ambasador Havlín, w tym samym dniu wicemarszałek sejmu Tadeusz Fiszbach poprosił wiceministra spraw zagranicznych Bolesława Kulskiego, aby wyjaśnił stronie czechosłowackiej delikatność całej sytuacji związanej z brakiem protestów ze strony klubu PZPR. Okazało się, że po przyjęciu rezolucji przez zdominowany przez opozycję Senat, klub poselski PZPR przygotował inny projekt, nieco „łagodniejszej” w swojej wymowie rezolucji, która miała zneutralizować wydźwięk tej pierwszej ${ }^{5}$. Zwracano w nim uwagę przede wszystkim na historyczny kontekst wydarzeń 1968 roku, np. adekwatne do sowieckich działania amerykańskie (Kuba, Dominikana, Grenada), wynikające z ówczesnego podziału świata na dwa przeciwstawne bloki, który teraz dyplomacja PRL stara się likwidować. W 1968 roku ważną rolę miały odgrywać też obawy, że sytuacja w Czechosłowacji wymknie się spod jakiejkolwiek kontroli, powodujac nieobliczalne konsekwencje dla polskiej racji stanu i interesów narodowych w kontekście nieunormowanych wówczas stosunków z RFN. Poza tym udział jednostek Wojska Polskiego w stłumieniu Praskiej Wiosny był nieporównywalny z wkroczeniem wojsk poskich na Zaolzie w 1938 roku, gdy Polska wespót z Niemcami hitlerowskimi dokonała $w$ istocie rozbioru Czechostowacji, który to fakt do dziś pozostaje negatywnym dla naszego narodu składnikiem świadomości Czechów i Stowaków, stąd ta sprawa bardziej zasługiwałaby na potępienie niż wydarzenia z 1968 roku. W końcowej części projektu klubu PZPR stwierdzano, że projekt opozycyjny jest sprzeczny z aktualnie obowiązującą w Czechosłowacji oficjalną oceną omawianych wydarzeń i taka próba jej weryfikacji bez liczenia się ze stanowiskiem najbardziej zainteresowanego państwa byłaby odebrana przez jego władze jako akt ingerencji, czyli tak samo jak zareagowałaby dziś Polska na jakiekolwiek oświadczenie innych państw odnoszqce się do aktualnego rozwoju sytuacji na jej obszarze ${ }^{6}$. Choć byłemu premierowi i wówczas już I sekretarzowi KC PZPR M. Rakowskiemu nie zależało na zaognianiu stosunków z Pragą w okresie polskiej transformacji, to jednak - zdaniem Kulskiego - było jasne, że podczas dyskusji sejmowej opozycja będzie miała i tak większe poparcie i wyraźnie liczy na dyskusję z PZPR w tej sprawie, co niewątpliwie dałoby wydźwięk propagandowy. Stąd także klub PZPR głosował za przyjęciem ostatecznej, tylko nieznacznie ,stonowanej” rezolucji Obywatelskiego Klubu Parlamentarnego (np. bez słów „agresja”), wybierając mniejsze zło ${ }^{7}$. Niezależnie od tego, M. Rakowski wystosował wcześniej list do marszałka Sejmu, w którym stwierdzał, że przyjęcie rezolucji skomplikuje

\footnotetext{
${ }^{5}$ AMZV, TOP, Informacja ambasady CSRS dla MSZ, 21.08.1989, k.2, č. 012850/89.

${ }^{6}$ Ibidem, Stanowisko w kwestii ewent.[ualnego] oświadczenia potęiajacego wkroczenie wojsk sojuszniczych do Czechostowacji w 1968 roku.

${ }^{7}$ Ibidem, Informacja ambasady CSRS dla MSZ, 21.08.1989....
} 
niepotrzebnie stosunki polsko-czechosłowackie, gdyż Czesi na pewno teraz przypomną Polakom haniebne zachowanie się przywódców Polski w okresie dogorywania Republiki Czechosłowackiej w 1938 roku. Kopię tego listu przekazano władzom czechosłowackim ${ }^{8}$. Bardziej szczegółowo o całej sprawie poinformował władze czechosłowackie ambasador PRL w Pradze, Włodzimierz Mokrzyszczak, który zreferował sekretarzowi KC KPCZ Józefowi Lenártowi przebieg związanego również z tym problemem XIV plenum KC PZPR. Okazało się, że 30 posłów zagroziło odejściem z klubu PZPR, o ile doszłoby do dyskusji nad rezolucją o 1968 roku, co groziłoby otwarciem drogi do próby zmiany konstytucji. Z kolejnych informacji Mokrzyszczaka władze czechosłowackie wywnioskowały, że PZPR słabnie i coraz szybciej traci wpływ na życie polityczne i społeczne w Polsce 9 . Oczekiwanej przez M. Rakowskiego antypolskiej kampanii prasowej na tematy historyczne w Czechosłowacji jednak nie było.

Jeśli chodzi o sprawy polskie, to następne dni upłynęły dyplomacji CSRS pod znakiem dyskusji nad kolejną inicjatywą władz rumuńskich, które na wieść o wyborze niekomunistycznego premiera PRL i perspektywie utworzenia rządu bez PZPR wystosowały w nocy z 19/20 sierpnia list do partii komunistycznych i robotniczych na temat konieczności wspomożenia PZPR w niedopuszczeniu do sformowania rządu reprezentanta opozycji i z oficjalnąjuż propozycją zorganizowania specjalnego spotkania na temat tej sytuacji. Najpierw jednak zareagowały władze polskie, wzywając w tym celu 22 sierpnia ambasadorów Bułgarii, Węgier, CSRS, NRD i ZSRR na rozmowę. Według relacji Havlína ze spotkania z Kulskim, władze PZPR nie zamierzały polemizować z władzami Rumuńskiej Partii Komunistycznej, ale pragnęły, aby Rumuni zrozumieli aktualne polskie realia. PZPR kieruje się bowiem interesem państwa i narodu, a te wymagają określonych rozwiązań, dla których nie ma już obecnie alternatywy. PZPR nadal też ma na uwadze interesy socjalizmu jako formacji społecznej i widzi jego zagrożenie. To, że PZPR zgodziła się na utworzenie władzy, w której byłyby reprezentowane wszystkie siły parlamentarne, nie znaczy, że wyrzeka się swojego wpływu na politykę państwa. PZPR ma silną pozycję w armii, służbie bezpieczeństwa i organach państwowych, a teraz będzie się starać o utrzymanie mocnej pozycji w nowych władzach. Gwarancją tego będzie także wybrany 19 lipca na urząd prezydenta generał Wojciech Jaruzelski. W dalszej części swojej wypowiedzi Kulski wystąpił przeciwko oskarżeniom, że uczestnictwo we władzy „Solidarności” służy najbardziej reakcyjnym kręgom imperializmu i nie jest to tylko sprawa Polski, wskazując na częste podtrzymywanie zasady nieingerencji przez Rumunię, zwłaszcza w 1968 roku, gdy odmówiła uczestnictwa w interwencji przeciwko Czechosłowacji. Polska nadal też jest wiarygodnym członkiem Układu Warszawskiego i RWPG. Poza tym w komunikacie uchwalonym na lipcowym posiedzeniu DKP wyraźnie stwierdzano, że nie istnieje uniwersalny model socjalizmu. Nadto Kulski prosił zebranych ambasadorów, aby zrozumieli trudne położenie PZPR i wpłynęli na swoje władze, tak aby w prasie ich krajów nie atakowano PRL i aby dały czas PZPR na wyjście z kryzysu. Poinformował ich również, że 21 sierpnia władze polskie otrzymały kolejny list z Bukaresztu, już nieco stonowany w treści. W swojej rela-

${ }^{8}$ Národní archiv České Republiky Praha, Ústřední výbor KSČ, Předsednictvo ÚV (dalej NÁ, PÚV, KSČ), List M. Rakowskiego do Marszatka Sejmu, syg.02/1, P 127/89/2, bod 9, č. 8412, svazek 121, archivní jednotka 127.

${ }^{9}$ Ibidem, Informacja o rozmowie ambasadora PRL z J. Lenártem, 21.08.1989, syg.02/1, P 127/89/2, bod 9, č. 8412 , sv. 122, a.j. 127. 
cji ze spotkania Havlín wstrzymał się tym razem od komentarzy ${ }^{10}$. Dzień później w podobnym tonie informował władze czechosłowackie ambasador PRL w Pradze, Włodzimierz Mokrzyszczak. Pytał również swojego głównego rozmówcę, sekretarza KC KPCz Lenárta o stanowisko władz CSRS w tej sprawie. Jednocześnie informowat, że KC PZPR ma niepotwierdzone informacje, wedlug których przywództwo chińskie miato się zwrócić do przywództwa KPZR z uwagami $i$ watpliwościami co do rozwoju sytuacji w niektórych krajach komunistycznych. Wspomniał poza tym, że nie moga [władze polskie-JR] uzyskać od organów czechostowackich informacji o obywatelach polskich zatrzymanych $w$ zwiqzku $z$ akcjami z 21 sierpnia [w rocznicę inwazji Układu Warszawskiego - JR] i zwrócit się w tej sprawie o pomoc. Zauważyl, że nie chcq sie [władze PRL - JR] za nimi ujmować, tylko zyskać informacje, aby była możliwość postępować wedtug odpowiednich przepisów. Polski ambasador przekazał także informację, że władze PZPR liczą iż w rządzie Mazowieckiego będą miały 4 ministrów, w tym szefa resortu obrony, choć aby osiagnąć zakładane cele, będą musiały silnie mobilizować swój klub poselski. Odpowiadając, Lenárt stwierdził, że na temat Chin władze czechosłowackie nic nie wiedza, a o ich stosunku do inicjatywy rumuńskiej strona polska zostanie poinformowana. W kwestii zatrzymanych polskich manifestantów proponował zwrócić się do $\mathrm{MSZ}^{11}$.

Tymczasem dyplomacja czechosłowacka sondowała opinie socjalistycznych stolic w sprawie listu RPK, który został wręczony także czechosłowackiemu ambasadorowi w Bukareszcie. Same władze partyjno-państwowe CSRS omawiały ten problem na posiedzeniu Biura Politycznego KC KPCz 25 sierpnia. W swoim stanowisku przejawiło ono obawy o los socjalizmu w PRL, ale pomysł wspólnego spotkania partyjnych liderów odrzuciło, proponując konsultacje bilateralne. Rozumiemy, że wobecnej sytuacji wzrasta znaczenie intensywniejszych kontaktów $i$ wspótpracy między bratnimi partiami, zwłaszcza po linii stosunków bilateralnych. Władze KSČ i naszego państwa utrzymuja systematyczne kontakty i aktywnq wymianę pogladów z polskimi dziataczami partyjnymi i państwowymi. Problem powołania niekomunistycznego premiera uznano za wewnętrzną sprawę Polski. 29 sierpnia Praga poznała odpowiedź dyplomacji węgierskiej, przekazaną także przez Budapeszt Rumunom. Opinie RPK na temat sytuacji w Polsce wywołały u władz węgierskich zdziwienie i dezaprobatę; sprzeciwiały się one proponowanym przez Bukareszt sposobom ingerowania w sprawy polskie, będąc zdania, że tzw. doktryna Breżniewa jest już pogrzebana. Podobnie jak w stanowisku polskim, była mowa o deklarowanych przez Rumunię pryncypiach nieingerencji w sprawy innych państw (przykład 1968 roku) oraz o zapewnieniach opozycji polskiej na temat poszanowania dotychczasowych sojuszy. W tym samym dniu swoim zaniepokojeniem, jeśli chodzi o rozwój sytuacji w Polsce, podzielili się wobec władz CSRS Kubańczycy, którzy również opowiadali się za poszanowaniem prawa do samostanowienia Polaków i kładli nacisk na stosunki bilateralne. Najważniejsza była oczywiście opinia ambasady sowieckiej, która została wówczas dostarczona liderom KPCz. Ambasador Wiktor Łomakin poinformował też o stanowisku przekazanym władzom rumuńskim. Najważniejszym chyba sformułowaniem było stwierdzenie, że takie spotkanie przywódców w sprawach Poski mogłoby w aktualnej sytuacji mieć zgoła odmienny efekt.

\footnotetext{
${ }^{10} \mathrm{AMZV}$, TOP, Informacja ambasady CSRS $w$ Warszawie dla MSZ, k.2, nr 012849/89.

${ }^{11}$ NÁ, PÚV KSČ, Informacja o przyjęciu ambasadora PRL przez J. Lenárta, 23.08.1989, syg.02/1, P 127/89/2, bod 9, č. 8412, sv. 122, a.j. 127.
} 
Sam fakt zwołania takiego forum by z pewnościa wykorzystała „Solidarność” i dalsze kregi opozycyjne w prezentowaniu PZPR jako sity, która reprezentuje nie interesy kraju, ale interesy zagranicznych partii i państw. Natomiast każda z tych partii może sama rozstrzygnąć co do swojej indywidualnej pomocy dla Polski. 31 sierpnia ambasador bułgarski podał do wiadomości, że stanowisko jego kraju jest takie samo jak KPCz, co wiązało się z rezultatem spotkania Todora Żiwkowa z Mieczysławem Rakowskim w Warnie 27 sierpnia. Co to oznaczało, trudno powiedzieć, ponieważ we wspólnym komunikacie polsko-bułgarskim ogłoszonym po spotkaniu stwierdzano tylko, iż w obu krajach przebiegają procesy odnowy i demokratyzacji społeczeństwa i że przebudowa polega nie tylko na skuteczności odnowy socjalizmu, ale i na obronie jego pryncypiów i ideałów ${ }^{12}$. Konkretnej odpowiedzi partii bułgarskiej dotyczącej sytuacji w Polsce archiwa czechosłowackie nie zawierają. Ale dla Pragi opinia Bułgarii i tak nie była decydująca. Po wejściu członków PZPR do rządu T. Mazowieckiego, w którym uzyskali oni funkcje wicepremiera, ministra spraw wewnętrznych, obrony, handlu zagranicznego i transportu, inicjatywa Bukaresztu straciła na znaczeniu.

Swoistym dyplomatycznym pożegnaniem na wysokim szczeblu komunistycznej Czechosłowacji z komunistyczną PRL była wizyta w Pradze M. Rakowskiego w dniu 28 września. Były polski premier kursował wówczas między stolicami „,bratnich krajów”, próbując wyjaśniać zachodzące w Polsce przemiany i prosić o wsparcie dla PZPR. W stolicy CSRS spotkał się wówczas z M. Jakešem, prezydentem G. Husákiem i premierem L. Adamcem. Według obszernego sprawozdania - przygotowanego przez Jakeša dla władz KC KPCz, informacje przekazywane przez Rakowskiego były jakby przeglądem całej sytuacji politycznej i społecznej, w jakiej znalazła się PZPR od początku 1989 roku, z licznymi odwołaniami do ważnych dla Polski wydarzeń z przeszłości (zacofana gospodarka w okresie międzywojennym, silna pozycja Kościoła katolickiego, błędy w polityce ekonomicznej w latach 70., wybór papieża Polaka). Przywódca PZPR stwierdził wprost, że nowe siły polityczne w Polsce dążą do likwidacji socjalizmu i nie wystawiał dobrego świadectwa ich polityce wewnętrznej i zagranicznej. Odnośnie do stosunków polsko-czechosłowackich Rakowski obiecał, że PZPR zawsze będzie występować przeciwko ich zaognianiu, nawiązując do wspomnianej rezolucji na temat 1968 roku, która jego zdaniem była błędem, ale z drugiej strony przywództwo PZPR nie kontroluje w pełni swojego klubu poselskiego. Do tej kwestii władze PZPR miały już nie wracać, gdyż w pełni respektują związane z tym stanowisko KPCz. W przypadku C̆SSR - kontynuował Rakowski - opozycja próbuje wypetniać jakaśs rolę misyjna, o czym świadczy rezolucja Sejmu i Senatu [...]. M. Rakowski zaznaczał, że w tej kwestii głupota opozycji nie zna granic. Prosił również stronę czechosłowacką o wsparcie, gdyż opozycja w Polsce musi wiedzieć, że PZPR nie jest sama, również na Zachodzie muszq to zrozumieć, a i członkowie partii muszq zyskać pewność, że maja poparcie przyjaciót. Rakowski podziękował zatem KPCz za gotowość pomocy $i$ wierzyt, że pomoga tak same inne partie, zwłaszcza towarzysze sowieccy; 29 września miał odbyć w tej sprawie spotkanie z Gorbaczowem. Twierdził też, że ze względu na skomplikowaną sytuację w całym świecie socjalistycznym spotkanie liderów partii komunistycznych mogłoby się stać dobrą okazją do otwartej wymiany poglądów. Na spotkaniu z Adam-

\footnotetext{
${ }^{12}$ Ibidem, Stanowisko PÚV KSČ wobec projektu władz RPK spotkania partii komunistycznych dla oceny rozwoju sytuacji w Polsce $i$ stanowiska innych partii wobec tego projektu, 25.08.1989 (z dodatkami), ibidem.
} 
cem Rakowski podkreślał, że PZPR będzie dbała o to, aby nie dopuścić do zerwania dwustronnych więzi ekonomicznych obu krajów. Jednocześnie prosił o konkretną pomoc poprzez rozwinięcie kontaktów handlowych. Opowiadał się także za intensyfikacją wzajemnych kontaktów partyjnych organów - „Trybuny Ludu” i „Rudego Prava”, poparł dalszą współpracę między czechosłowacką centralą związków zawodowych (ROH) a Ogólnopolskim Porozumieniem Związków Zawodowych. W zachowanej czechosłowackiej wersji relacji z omawianego spotkania odnotowano jedynie wypowiedź Jakeša, który informował polskiego gościa o przebiegu reformy gospodarczej w Czechosłowacji oraz zaznajomit M. Rakowskiego ze stanem przygotowań do XVIII zjazdu KSČ, z polityka partii w procesie demokratyzacji [...]. Położył nacisk na to, że jeśli partia ma być na czele „přestavby”, to nie może dopuścić do totalnej negacji minionego rozwoju, prezentowania socjalizmu jako łańcucha błędów i omyłek. Jakeš stwierdzał też, że w Pradze w pełni zdają sobie sprawę z sytuacji, w której PZPR obecnie się znajduje, i z konieczności nowego podejścia do współpracy międzynarodowej. Zapewnił gościa, że będzie rozwijana współpraca w kierunku uchronienia i dalszego wzmocnienia na przyszłość socjalistycznego charakteru społeczeństwa w PRL. Jednak żadnych konkretnych ustaleń nie było ${ }^{13}$.

Problemem, który dodatkowo ciążył na stosunkach czechosłowacko-polskich, choć bardziej w odczuciach strony polskiej, było także jednostrone wstrzymanie przez Pragę z dniem 7 grudnia 1981 roku indywidualnego ruchu granicznego, w tym także tzw. małego ruchu granicznego między obu krajami, co dotyczyło zarówno obywateli polskich jak i czechosłowackich. Przez następne lata władze polskie naciskały na stronę czechosłowacką w kwestii rozluźnienia tych restrykcji, mając na uwadze także kwestie tranzytowe i ruch lokalny na pograniczu. Największy problem był z ruchem indywidualnym. W końcu czerwca 1982 roku szef dyplomacji CSRS Bohuslav Chňoupek przesłał swoim władzom rządowym projekt, który zakładał możliwość przekraczania granicy krewnym (rodzice, małżonkowie, dzieci) stale zamieszkałych lub czasowo zatrudniowych osób w obu państwach cztery razy w roku, na podstawie urzędowo potwierdzonego zaproszenia, a tranzyt ograniczono do 24 godzin, po okazaniu dokumentów i legalnych środków pieniężnych uprawniających do wjazdu na teren trzeciego państwa. Dopuszczano krótkie wizyty z przyczyn losowych (np. pogrzeb), ale tylko dla najbliższych krewnych (jednak nie obejmowało to rodzeństwa). Projekt w formie uchwały rządowej wszedł w życie z dniem 1 lipca 1982 roku, choć władze uzależniały jej praktyczną realizację od postępujacej normalizacji $w$ Polsce. Podjęte decyzje z litery prawa były oczywiście sprzeczne z duchem umowy z PRL o ruchu bezwizowym z 1977 roku i ustawą o zasadach podróżowania z 1965 roku. Władze KPCz na to jednak nie zważały, gdyż liczyła się ochrona własnego rynku konsumpcyjnego i niedopuszczenie, z przyczyn politycznych, do bezpośrednich kontaktów obywateli CSRS z Polakami, choć na użytek propagandowy tłumaczyły własnym obywatelom, iż jest to żądanie strony polskiej. Sytuacja nie zmieniła się, gdy rok później Polska otworzyła granice dla obcokrajowców. Pragnący udać się do Polski obywatele CSRS byli zawracani przez własne służby graniczne, chyba że wjeżdżali od strony NRD. Na kolejne zmiany Praga zgodziła się w 1985 roku, roszerzając od 1 sierpnia krag członków rodziny mogących odwiedzać swoich krewnych oraz umożliwiając odwiedziny przygranicznych cmentarzy w dniach 1-2 listopada wszystkim posiadającym

${ }^{13}$ Ibidem, Informacja M. Jakeša dla PÚV KSČ o rozmowie z I sekretarzem KC PZPR M. Rakowskim, 28.09.1989, syg. 02/1, P 132/82/2, bod 8, č. 8686, sv.126, a.j.132. 
tam groby bliskich ${ }^{14}$. Generalnie strona czechosłowacka z przyczyn politycznych i ekonomicznych nie była zainteresowana przywróceniem dawnego stanu i w następnych latach nie doszło do większego przełomu w tej dziedzinie. Nie wpływało to pozytywnie na całokształt stosunków między obu krajami w 1989 roku i jakby zaprzeczało deklaracjom Pragi odnośnie do politycznego wspomagania słabnącej PZPR.

Ostatecznie, po doświadczeniach polskich i węgierskich oraz obserwacji przemian w ZSRR, ale zwłaszcza losu PZPR w Polsce, w drugiej połowie 1989 roku władze czechosłowackie doszły do wniosku, że jakiekolwiek większe zmiany systemowe w ich własnym kraju zagrożą przede wszystkim zajmowanej przez nie pozycji. Stąd bliżej było wówczas Pradze do Sofii, Berlina, czy Bukaresztu niż do innych stolic. Ponadto w tym czasie przestały już napływać z Kremla wytyczne co do kierunków w polityce wewnętrznej i zagranicznej, do których KSČ była przyzwyczajona. Mimo zapowiedzi, że poprze PZPR, wybrała więc izolowanie Czechów i Słowaków od Polski i Polaków, poza tym ograniczenie ewentualnych reform do sfery gospodarczej. Trudno powiedzieć, czy przywódcy ČSSR liczyli w ten sposób na pozostawanie u władzy przez następne lata, ale na pewno nie przypuszczali, że potrwa ona jeszcze tylko parę miesięcy.

\section{(Z języka czeskiego przełożył Krzysztof Nowak)}

\section{Bibliografia}

Archiwalia:

Archiv Ministerstva zahraničních věcí Praha

- Teritoriální odbory-tajné, Polsko

Národní archiv České Republiky Praha

- Ústřední výbor KSČ, Předsednictvo ÚV

Opracowania:

Rychlík J., Cestováni do ciziny v habsburské monarchii a v Československu. Pasová, vizová a vystěhovalecká politika 1848-1989, Praha 2007.

Rychlík J., Politické změny ve Východni Evropě před 17. listopadem a jejich ohlas v Československu, „Česko-slovenská historická ročenka” 2009.

Jan Rychlík, w 1979 r. ukończyl studia z zakresu etnologii i historii na Uniwersytecie Karola w Pradze, w 1985 r. uzyskal doktorat w Zakładzie Folklorystyki Bułgarskiej Akademii Nauk, zaś w 1998 r. doktorat z historii w Zakładzie Historii Akademii Nauk Republiki Czeskiej. Jest profesorem nowoczesnej historii Czech i Słowacji w Zakładzie Historii Czech Wydziału Filozoficznego Uniwersytetu Karola w Pradze i pracownikiem naukowym Instytutu Masaryka i Archiwum Akademii Nauk Republiki Czeskiej. Doktor honorowy Uniwersytetu im. św. Klimenta Ohridskiego w Sofii. Zajmuje się historią Czech, Słowacji i krajów bałkańskich.

jan.rychlik@ff.cuni.cz

${ }^{14}$ Szerzej zob. J. Rychlík: Cestovani do ciziny v habsburske monarchii a v Československu. Pasova, vizova a vystěhovalecka politika 1848-1989, Praha 2007, s. 91-96, 101-102, 228-241. 